\title{
In vitro maturation and fertilisation of bovine oocytes in relation to GH gene polymorphism (Leu/Val)
}

\author{
Dorota LeChniaK*, Tatiana AdAMOWICZ, Daniel StanisŁaWsKi, \\ Dorota KACZMAREK
}

\author{
August Cieszkowski, Agricultural University of Poznan, Department of Genetics \\ and Animal Breeding, Wolynska 33, 60-637 Poznan, Poland
}

(Received 23 January 2002; accepted 21 May 2002)

\begin{abstract}
The present study describes the analysis of the associations between the growth hormone gene polymorphism (Leu/Val) and oocyte maturation and in vitro fertilisation in cattle. Two independent experiments were carried out. In the first one, oocytes were collected from 49 single ovaries, matured in vitro, measured and cytogenetically analysed. One ovary was considered as a donor. The procedure of the donor's genotyping at the GH locus was based on DNA extracted from the granulosa cells. The GH genotype did not influence the oocyte diameter nor the number of oocytes collected, which were selected for maturation and matured. An unreduced chromosome number was found in $8.8 \%$ of the cells at the second metaphase stage and $42.9 \%$ of the donors. This anomaly was observed in all genotype groups with a higher frequency in the VV cows $(P<0.01)$. In the second experiment, the oocytes collected from 72 single ovaries were matured and fertilised in vitro. The $\mathrm{GH}$ genotype of a donor did not influence the number of zygotes cleaved on day-2. It has to be mentioned, that due to the low frequency of the VV genotype (0.03), the results of the present study should be treated as preliminary and need further analysis.
\end{abstract}

oocyte / in vitro maturation / GH polymorphism

\footnotetext{
* Correspondence and reprints

E-mail: lechniak@jay.au.poznan.pl
} 


\section{INTRODUCTION}

A growing body of evidence suggests that the growth hormone $(\mathrm{GH})$ also plays an important role in mammalian reproduction. The GH gene is expressed in bovine oocytes and preimplantation embryos [8]. A positive effect of exogenous $\mathrm{GH}$ on oocyte maturation and embryonic development in cattle has also been shown [3-5]. In the bovine growth hormone gene, several point mutations have been reported, but the best characterised one is the Leu127Val polymorphism in the fifth exon [14]. Some associations have been reported between the three polymorphic forms and GH concentration in blood and its pulsative secretion in cattle [2, 13].

It is known that the oocyte diameter is one of the factors influencing its ability to resume and complete meiosis in vitro. Fair et al. [1] showed that oocytes smaller than $110 \mu \mathrm{m}$ have a reduced ability to resume meiosis. Recently, Lechniak et al. [9] reported a correlation between oocyte size and disturbances in meiotic division in vitro, especially for the failure of the first polar body extrusion.

The aim of the present study was to analyse the influence of the GH genotype of a cow on the following traits: (i) the number of oocytes suitable for in vitro maturation (IVM), (ii) oocyte diameter, (iii) the frequency of the diploid chromosome number in secondary oocytes and (iv) the rates of matured oocytes and zygotes cleaved on day 2 .

\section{MATERIALS AND METHODS}

\subsection{Experiment 1}

Cumulus-oocyte-complexes (COC) were obtained by slicing ovaries collected at a local slaughterhouse. The slaughtered cows were mainly of the Polish Friesian breed. Single ovaries were randomly picked up from a pool of gonads collected at the abattoir and one ovary was considered as a donor. Therefore it cannot be excluded that 2 analysed ovaries may have originated from the same cow. A COC was classified as suitable for in vitro maturation when several layers of non-expanded cumulus cells were present and when the oocyte contained an evenly granulated ooplasm. All oocytes showing either signs of cumulus cell expansion or dark, shrunken and degenerated ooplasm were discarded. IVM was carried out in TCM 199 supplemented with $10 \%$ FCS and hormones $\left(2 \mu \mathrm{g} \cdot \mathrm{mL}^{-1} \mathrm{FSH}\right.$, $10 \mu \mathrm{g} \cdot \mathrm{mL}^{-1} \mathrm{LH}, 1 \mu \mathrm{g} \cdot \mathrm{mL}^{-1} \beta$-estradiol) in a humidified $5 \% \mathrm{CO}_{2}$ atmosphere for $24 \mathrm{~h}$ at $38.5^{\circ} \mathrm{C}$. Oocytes were matured in groups reflecting their origin from individual ovaries. At the same time follicular cells collected from each ovary were washed in $0.9 \%$ sodium chloride and frozen for further DNA analysis.

The protocol described by Lechniak et al. [9] was used for oocyte size determination.

Cytogenetic slides were made according to Tarkowski's [15] method and were stained with $5 \%$ Giemsa.

Genomic DNA was isolated from follicular cells collected from each ovary by proteinase $\mathrm{K}\left(20 \mathrm{mg} \cdot \mathrm{mL}^{-1}\right)$ digestion followed by phenol/chloroform extraction and ethanol precipitation.

The following pair of primers spanning the 4th and 5th GH gene exons were designed and used for cow genotyping:

$$
\begin{gathered}
\text { GH-1 5' - AGA AGC TGA AGG ACC } \\
\text { TGG AG - 3', } \\
\text { GH-2 3' - AAG CGG CGG CAC TTC } \\
\text { ATG AC - 5'. }
\end{gathered}
$$

A 492-bp fragment was amplified. The PCR products were digested with Alu I enzyme (restriction site-5'..AG/CT..3'; Fig. 1).

The effect of the GH genotypes on the analysed traits (number of oocytes collected, matured, diploid and cleaved zygotes) in individual donors was analysed by the use of the SAS statistical package (Procedure 


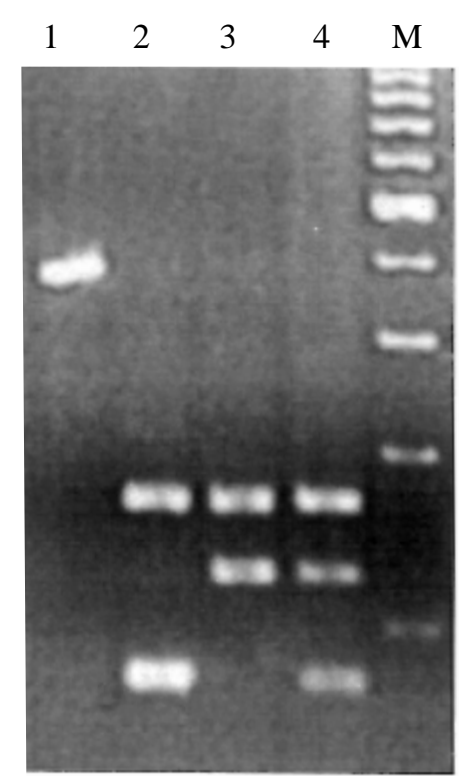

Figure 1. Analysis of the Leu/Val RFLP polymorphism in the bovine growth hormone gene: 1 - non-digested PCR product (428 bp); 2 - the LL genotype (263, $173 \mathrm{bp}) ; 3$ - the VV genotype (263, $224 \mathrm{bp}) ; 4$ - the LV genotype ( 263 , 224, $173 \mathrm{bp}$ ); M - DNA size marker (100 bp DNA ladder).

means GLM, FREQ, CORR) and also the Duncans Multiple Range Test on all main effect means (genotype, maturation stage, cow nested within the genotype).

\subsection{Experiment 2}

The IVM/IVF/IVC protocol described by $\mathrm{Xu}$ et al. [16] was applied. Briefly, COCs were collected by slicing single ovaries and were matured in groups reflecting their origin from individual ovaries. Matured oocytes were inseminated by the motile fraction of sperm cells separated by the swim-up procedure produced by bulls of known fertilising potential in vitro. Gametes were coincubated for $18 \mathrm{~h}$. The presumptive zygotes were co-cultured with bovine oviduct epithelial cells. Cleavage rate was evaluated on day-2 post insemination.

\section{RESULTS}

\subsection{Experiment 1}

Altogether, 2114 COCs were collected from 49 single ovaries, and $54.8 \%$ of them were suitable for the IVM procedure according to the criteria described in the Material and Methods section. Chromosome slides were prepared for $85.4 \%$ of maturated oocytes and $59.4 \%$ of them could be cytogenetically analysed. The second metaphase stage (MII) was reached by $71.4 \%$ (420/588) of the analysed cells (Tab. I).

According to the statistical analysis, the GH genotype did not significantly influence the number of oocytes collected, accept for IVM and matured oocytes.

The unreduced set of chromosomes was found in 37 oocytes at the MII stage (37/420; $8.8 \%)$ as well as in 21 cows $(42.9 \% ; 21 / 49)$. This anomaly was observed in all genotype groups with a higher frequency for the $\mathrm{VV}$ cows $(P<0.01$; Tab. I).

The mean oocyte diameter was $114.5 \mu \mathrm{m}$. No significant differences were noticed among the cows according to the GH genotype (Tab. I).

\subsection{Experiment 2}

In total, 2903 COCs and consequently 1262 day- 2 embryos were derived from 72 single ovaries. On average, 40 COCs suitable for IVM were collected and 17 embryos were produced per ovary (Tab. II). Statistical analysis did not show any significant differences according to the number of collected oocytes and produced embryos by donors with three different GH genotypes.

\section{DISCUSSION}

The bovine ovary has been shown to be a site of GH action; it influences the follicle and oocyte growth as well as oocyte 
maturation [7, 12, 17]. Moreover, GH stimulates in vitro oocyte maturation as well as embryo development in cattle [3-5].
In the present study, the GH genotype of a donor did not significantly influence oocyte maturation and cleavage rate on

Table I. Analysed traits with regards to the cow's genotype at the GH locus.

\begin{tabular}{|c|c|c|c|}
\hline \multirow[t]{2}{*}{ Numbers of oocytes } & \multicolumn{3}{|c|}{ Genotype } \\
\hline & LL & LV & VV \\
\hline \multicolumn{4}{|l|}{ Collected } \\
\hline Total & 1115 & 816 & 183 \\
\hline Per cow \pm SD & $42.9 \pm 17.5$ & $42.9 \pm 26.0$ & $45.7 \pm 16.7$ \\
\hline \multicolumn{4}{|l|}{ Accepted } \\
\hline Total & 636 & 434 & 89 \\
\hline Per cow \pm SD & $24.5 \pm 11.2$ & $22.8 \pm 11.1$ & $22.3 \pm 10.4$ \\
\hline \multicolumn{4}{|l|}{ Analysed $^{1}$} \\
\hline Total & 293 & 238 & 57 \\
\hline Per cow \pm SD & $11.3 \pm 3.5$ & $12.5 \pm 6.6$ & $14.3 \pm 8.5$ \\
\hline \multicolumn{4}{|l|}{ Matured $^{2}$} \\
\hline Total & 199 & 177 & 44 \\
\hline Per cow \pm SD & $7.7 \pm 3.3$ & $9.3 \pm 5.8$ & $11.0 \pm 5.9$ \\
\hline \multicolumn{4}{|l|}{ Diploid $^{3}$} \\
\hline Total & 15 & 13 & 9 \\
\hline Per cow \pm SD & $0.6 \pm 0.7^{\mathrm{a}}$ & $0.7 \pm 1.2^{\mathrm{a}}$ & $2.3 \pm 2.6^{b}$ \\
\hline$\%$ & 7.5 & 7.3 & 20.5 \\
\hline \multicolumn{4}{|l|}{ Mean diameter ( $\mu \mathrm{m})$} \\
\hline All cells $\pm \mathrm{SD}$ & $114.2 \pm 7.1$ & $115.1 \pm 7.1$ & $113.6 \pm 8.7$ \\
\hline Diploid \pm SD & $114.4 \pm 5.8$ & $115.4 \pm 7.6$ & $107.9 \pm 6.7$ \\
\hline
\end{tabular}

a,b Lines with different superscripts differ significantly.

${ }^{1}$ Oocytes analysed cytogenetically (with recognised meiotic stage).

2 Oocytes at the MII stage (including diploid cells).

${ }^{3}$ Oocytes with an unreduced number of chromosomes.

SD: standard deviations.

Table II. Embryo production based on oocytes collected from cows of various GH genotypes.

\begin{tabular}{|c|c|c|c|c|c|c|}
\hline \multirow[t]{3}{*}{ Genotype } & \multirow{3}{*}{$\begin{array}{c}\text { Donors } \\
\%\end{array}$} & \multicolumn{5}{|c|}{ Number of oocytes } \\
\hline & & \multicolumn{2}{|c|}{ Collected } & \multicolumn{3}{|c|}{ Cleaved } \\
\hline & & Total & Mean & Total & Mean & $(\%)$ \\
\hline LL & $40(55.6)$ & 1541 & 38 & 633 & 16 & (41.1) \\
\hline LV & $25(34.7)$ & 982 & 40 & 450 & 18 & (45.8) \\
\hline VV & $7(9.7)$ & 380 & 54 & 179 & 26 & (47.1) \\
\hline
\end{tabular}


Day 2. A very low frequency of the VV form usually observed among dairy breeds may be one of the limiting factors affecting the statistical analysis. The highest incidence of diploid oocytes in VV cows was the only trait that differentiated the donors with various $\mathrm{GH}$ genotypes. Oocytes with an unreduced chromosome number were found in three out of four VV cows (75\%). It has to be mentioned here that individual ovaries representing donors were randomly picked out from a pool of ovaries collected at the abattoir. Therefore, 4 ovaries referred to as $4 \mathrm{VV}$ cows may have originated from less than 4 distinct cows. Moreover, the observed relationship can be significantly influenced by the unequal distribution of 9 diploid cells among VV donors: one of them produced 6 abnormal cells that equalled $66.7 \%$ of all diploid oocytes found in this group of cows.

Diploidy accounts for the most frequently observed chromosome abnormality among secondary oocytes matured in vitro. The failure of the first polar body extrusion has been shown to be the main cause of unreduced chromosome number $[6,10]$. Oocyte diameter is related to the ploidy of the secondary oocytes in cattle [9]. Smaller oocytes more frequently display unreduced sets of chromosomes. GH stimulates IVM of bovine oocytes and may affect the kinetics of the first polar body extrusion directly or through its main mediator - IGF I, which has been shown to accelerate this process $[3,4,11]$.

Since the GH polymorphism has been shown to be related to growth hormone concentration and its pulsative secretion in animals of various $\mathrm{GH}$ genotypes [2, 13], it can be suspected that these differences may also affect the kinetics of oocyte in vitro maturation in cattle. Considering the limitations of this study, the present results have to be treated as preliminary and need further investigation.

\section{REFERENCES}

[1] Fair T., Hyttel P., Greve T., Bovine oocyte size in relationship to follicular diameter, maturational competence and RNA synthesis, Theriogenology 43 (1995) 209.

[2] Grochowska R., Sørensen P., Zwierzchowski L., Snochowski M., Løvendahl P., Genetic variation in stimulated GH release and IGF-I of young dairy cattle and their associations with the leucine/valine polymorphism in the GH gene, J. Anim. Sci. 79 (2001) 470-476.

[3] Izadyar F., van Tol H.T.A., Colenbreander B., Bevers M.M., Stimulatory effect of growth hormone on in vitro maturation of bovine oocytes is exerted trough cumulus cells and not mediated by IGF-I, Mol. Reprod. Dev. 47 (1997) 175-180.

[4] Izadyar F., Zeinstra E., Bevers M.M., Folliclestimulating hormone and growth hormone act differently on nuclear maturation while both enhance developmental competence of in vitro matured bovine oocytes, Mol. Reprod. Dev. 51 (1998) 339-345.

[5] Izadyar F., Hage W.J., Colenbrander B., Bevers M.M., The promotory effect of growth hormone on the developmental competence of in vitro matured bovine oocytes is due to improved cytoplasmic maturation, Mol. Reprod. Dev. 49 (1998) 444-453.

[6] King W.A., Chromosome abnormalities and pregnancy failure in domestic animal, Adv. Vet. Sci. Comp. Med. 23 (1990) 229-250.

[7] Kolle S., Sinowatz F., Boie G., Lincoln D. Developmental changes in the expression of the growth hormone receptor messenger ribonucleic acid and protein in the bovine ovary, Biol. Reprod. 59 (1998) 836-842.

[8] Lechniak D., Betts D.H., Kawarsky S.J., King W.A., Growth hormone gene is expressed in preattachment bovine embryos, J. Reprod. Fertil. Abstr. Ser. 23 (1999) 81.

[9] Lechniak D., Kaczmarek D., Stanisławski D., Adamowicz T., The ploidy of in vitro matured bovine oocytes is related to the diameter, Theriogenology 57 (2002) 1303-1308.

[10] Ocana-Quero J.M., Pinedo-Merlin M., MorenoMillan M., Influence of follicle size, medium, temperature and time on the incident of diploid bovine oocytes matured in vitro, Theriogenology 51 (1999) 667-672.

[11] Sakaguchi M., Dominko T., Leibfried-Rutledge M.N., Nagai T., First N.L., A combination of EGF and IGF-I accelerates the progression of meiosis in bovine follicular oocytes in vitro and fetal calf serum neutralizes the acceleration effect, Theriogenology 54 (2000) 1327-1342.

[12] Schams D., Berisha B., Kosmann M., Einspanier R., Amselgruber W.M., Possible role of growth hormone, IGFs and IGF-binding proteins in the regulation of ovarian function in large farm animals, Domest. Anim. Endocrinol. 17 (1999) 279-285. 
[13] Schlee P., Graml R., Schallenberger E., Schams D., Rottmann O., Olbrich-Bludau A., Pirchner F., Growth hormone and insulin-like growth factor I concentrations in bulls of various growth hormone genotypes, Theor. Appl. Genet. 88 (1994) 497-500.

[14] Seavey B.K., Singh R.N.P., Lewis U.J., Geschwind J.J., Bovine growth hormone: evidence for two allelic forms, Biochem. Biophys. Res. Commun. 43 (1971) 189-195.

[15] Tarkowski A.K., An air-drying method for chromosome preparation from mouse eggs, Cytogenetics 5 (1966) 394-400.
[16] Xu K.P., Yadav B.R., Rorie R.W., Plante L. Betteridge K.J., King W.A., Development and viability of bovine embryos derived from oocytes matured and fertilised in vitro and cocultured with bovine oviductal cells, J. Reprod. Fertil. 94 (1992) 33-43.

[17] Yoshimura Y., Iwashita M., Karube M., Oda T., Akiba M., Shiokawa S., Ando M., Yoshinaga A., Nakamura Y., Growth hormone stimulates follicular development by stimulating ovarian production of like-like growth factor-I, Endocrinology 135 (1994) 887-894. 